\title{
Heterotrimeric G Protein Subunit Gene
}

National Cancer Institute

\section{Source}

National Cancer Institute. Heterotrimeric G Protein Subunit Gene. NCI Thesaurus. Code C26191.

Heterotrimeric G Protein Subunit Genes encode Heterotrimeric G Protein signal transducers, attached to the plasma membrane, that connect seven transmembrane cell surface G-protein coupled receptors to intracellular signal transduction effectors and pathways. Inactive G proteins consist of alpha/beta/gamma complexes that signal as dissociated GTP-bound alpha subunit or the beta/gamma complex. GTP hydrolysis by the inherent GT Pase reverts the alpha subunit to its inactive (heterotrimeric) form. Receptors coupled to G proteins communicate signals from hormones, neurotransmitters, chemokines, and autocrine and paracrine factors. $(\mathrm{NCl})$ 